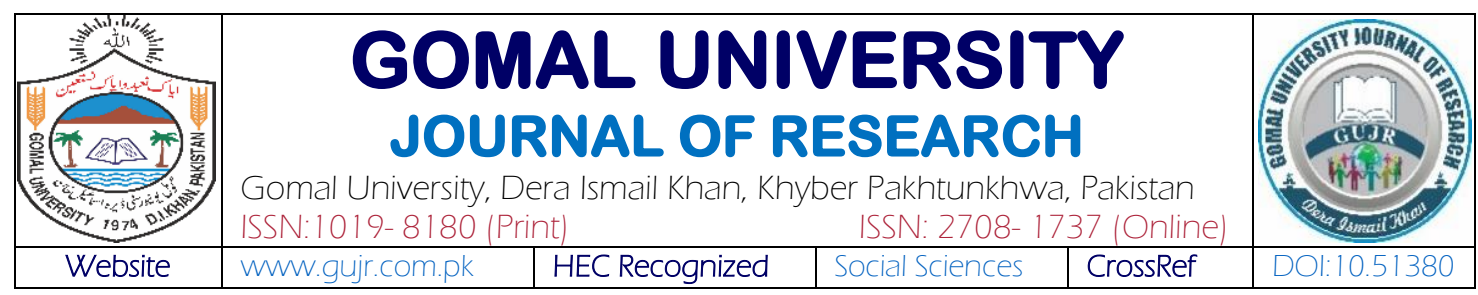

\title{
AN INVESTIGATION ON COVID-19 CONSPIRACY THEORY BELIEFS AMONGST PAKISTANI MUSLIMS
}

\author{
Mujeeba Ashraf \\ Assistant Professor, Institute of Applied Psychology, University of the Punjab, Lahore, Pakistan
}

\section{\begin{tabular}{l|l} 
KEYWORDS & ABSTRACT
\end{tabular}}

COVID-19, Conspiracy

Theory, Beliefs,

Pakistani Muslims

\section{Article History}

Date of Submission:

01-02-2021

Date of Acceptance:

20-09-2021

Date of Publication:

30-09-2021
With the COVID-19 pandemic gripping world, there has been an alarming increase in role of conspiracy theories generated surrounding COVID-19.

Thus, this research aims to understand what conspiracy beliefs Pakistani Muslims may possess about COVID-19. The research followed correlational research design. The data was collected through an online self-reported COVID-19 Conspiracies Belief Questionnaire from 110 Pakistani Muslims with a mean age of 25.40 and SD of 5.73. Descriptive statistics explained that 59\%, 60\%, 79\% of the participants agree with the conspiracy that it accidentally escaped from the Chinese lab, planted by the American Army in China to destroy China's economy, and it is a punishment from Allah for human sins respectively. Chi-square analysis revealed that females believe more in conspiracies as compare to male research participants. Moreover, binary logistic regression explained that COVID-19 is a way to control the world by developing psychological fear. The findings may enable local and national governing bodies to develop the knowledge-based strategies to tackle conspiracy beliefs.

\section{(c) $\rightarrow$ ()}

2021 Gomal University Journal of Research

\begin{tabular}{l} 
Corresponding Author \\
\hline $\mathrm{OI}$
\end{tabular}

Mujeeba Ashraf: mujeebaashraf009@gmail.com

https://doi.org/10.51380/gujr-37-03-10

\section{INTRODUCTION}

Pandemics are a continuous threat to humankind because these caused premature deaths than any other disease, for example, during 1918 influenza pandemic, more than 50 million deaths were reported (Graham \& Sullivan, 2018; Morens, Daszak \& Taubenberger, 2020). Historically, whenever pandemic has occurred, conspiracy theories have emerged and efforts have been made to speed progression. For instance, in 14th century during Black Death in Europe, conspiracy theories advocated that the Jewish people were the source of the plague. More recently, African Americans and gay people were considered responsible for spreading AIDS epidemic in USA (Bates, 1990; Cooper, 1990; Douglass, 1989). When COVID-19 pandemic gripped the world early in 2020, there was alarming increase conspiracy theories surrounding COVID-19. Indeed, with rise of the social media, the declining levels of trust in the official institutions and growth in anti- 
establishment political movements, conspiracy theories have become more 'mainstream' than ever before.

On social media in March 2020, various posts circulated about the emergence of COVID-19, few of which stated that the virus had emerged from a laboratory in Wuhan, China, where bats were tested. It was claimed that virus accidentally escaped from there. Few posts and videos suggested that it was bio weapon developed by US or China as part of economic war. Other posts advised that Bill Gates was trying to control people by injecting bio chips into humans in guise of vaccine. Several Muslims posted videos which suggested that this virus was part of an attempt by Israel to become a Greater Israel, and a few posts by Muslims argued that the pandemic was brought upon us because of LGBT movements and that it had been imposed as a punishment by Allah for our sins. The fact that even Muslims were forbidden to enter Harram, Mecca, showed that Allah was not happy with us. Moreover, various posts circulated on social media which claimed that this virus is fake and an attempt to control people by fostering fear. Researchers claimed that social media played a pivotal role in spreading conspiracy beliefs (Avaaz, 2020; Oi-Yee Li, Bailey, Huynh \& Chan, 2020; Pandey, Patni, Sing, Sood \& Singh, 2020; Martínez \& Jiménez, 2017).

When medical science fails to allay fear of a contagious disease it is a usual pattern that people start to believe in conspiracy theories in order to counter their fears and anxieties, to maintain control and feel secure. This can be explained by one of components, i.e. the existential social psychological motive, of system justification theory (Jost, Ledgerwood \& Hardin, 2008). The literature supports this kind of motivation behind conspiracy beliefs as research has shown that people believe in them not only to gain control (Goertzel, 1994) but also to counter their anxieties (Grzesiak, 2013; Abalakina, Stephan, Craig \& Gregory, 1999). Experimental studies also show that people start to believe in conspiracy theories when they feel themselves powerless to control the outcome of situation (Prooijen \& Douglas, 2015). Research also reflects upon demographic characteristics of those who are prone to conspiracy theories, such as level of the education and income, gender, ethnicity, job status (Uscinski \& Parent, 2014; Freeman \& Bentall, 2017; Hogg, Nkala, Dietrich, Collins, Closson, Cui \& Kaida, 2017). With regard to COVID-19, Pew Research Center in USA released results of a survey conducted in April 2020, according to which $43 \%$ of Americans believe that it has occurred naturally while $23 \%$ believe that it was intentionally created in lab.

\section{LITERATURE REVIEW}

The previous research explained that during Ebola and Zika outbreak Youtube videos contained misleading information regarding crises (Pandey, Patni, Sing, Sood \& Singh, 2010). It was also found that American people who used Facebook their frequent exposure to fake news increased their belief in fake news (Pennycook, Cannon \& Rand, 2018). About COVID-19 recent research indicated that $25 \%$ of videos related to COVID-19 on Youtube have misleading information which had 62 million views (HO et al, 2020). Similarly, the survey by Ofcom in Britain revealed that half of the adult British population had exposed to misleading online information. Moreover, Miller (2020) studied 3,019 American adults and advocated that the people who believe in the conspiracies related to COVID-19 have a monological belief system, if a person believes in one conspiracy, then he/she would believe the another conspiracy too. Similarly, Uscinski, Enders, Seelig, Funchion, Everett and Murthi (2020) researched sample of 2000 Americans and found that $29 \%$ of the research participants were agreed with the conspiracy theory that COVID-19 
was spread to damage President Trump, and $31 \%$ believed that it was man-made and spread purposefully.

In term of the demographics, research advocate that older people had higher susceptibility to misinformation than younger people (Guess, Nagler \& Tucker, 2019). In the context of COVID19, Sallam, Dababseh, Yaseen, Haidar, Ababneh, Bakri and Mahafzah (2020) studied the 1540 students with the mean age of 22 years in Jorden. They found that most of the students had a belief in conspiracy theories related to COVID-19, and females with lower socioeconomic status had a belief that COVID-19 is related to the conspiracy. Additionally, those who had believe in conspiracy theories also scored higher on the anxiety scale. In this connection, another research conducted by Duplaga (2020) on 1002 polish adults and found that 43 to $56 \%$ of their sample was a belief in COVID-19 related conspiracy theories, and it was significantly related to the age, education, and professional status. Aside, some studies indicated that belief in the conspiracy theories affects the public health behavior in different contexts and situations. For example, Kalichman (2009) found that those people who believe in a conspiracy that HIV is a man-made virus and had a purpose to commit genocide of African's were less likely to do testing for early detection.

Similarly, those who believe in the conspiracy theories related to Zika Virus tended to show less intentions to get vaccination (Dredze et al., 2016). Similarly, regarding COVID-19, Uscinski, Enders, Seelig, Funchion, Everett and Murthi (2020) reported that belief in the conspiracies during COVID-19 associated with reduced willingness to adhere to public health guidelines and belief in conspiracy theories people had less trust in WHO approach to handling the situation of COVID-19. Smilarly, Plohl and Musil (2020) also explained that conspiracy ideation did not directly predict compliance to preventive measures for COVID-19 in 525 international research participants. Moreover, those who had believe in conspiracy theories also scored higher on the anxiety scale. In this connection, the above-cited literature indicated that the people's belief in conspiracy theories relates to COVID-19 and their belief in the conspiracy affects their mental health as well as their practices to follow public health safety measures related to COVID-19. Therefore, it is essential to study whether Pakistani Muslims believed in conspiracy theories related to COVID-19 or not and which demographics were associated with belief in conspiracy theories.

Young adults between the ages of 18 and 29 years were more likely to be of opinion that it was created in lab while those who had at least high-school qualifications were more likely to believe that it was created in lab. However, there has been no published information about prevalence of belief in conspiracy theories among Pakistani Muslims regarding COVID-19. Nor has there been any attempt to find out that which demographic variables are associated with the belief in conspiracies related to COVID-19. Therefore, aim of this research is to understand what type of conspiracy beliefs Muslims have tended to hold during COVID-19 pandemic in Pakistan. This study was designed to find out that how many respondents believe in which conspiracy, and to observe gender differences in belief in conspiracy theories. In addition, the association between demographic characteristics (age, gender, education, occupation, monthly income \& ethnicity) and the belief in conspiracy theories was investigated. Therefore, an attempt was also made to determine whether there was a generalised tendency to believe in conspiracy theories among Muslims. 


\section{RESEARCH METHODOLOGY}

The methods and procedures for conducting research are offered in this section. The research followed correlational research design. Data were collected from 110 adults Pakistani Muslims between May and June 2020. The data were collected through an online self-reported survey that was promoted over social media such as Facebook, Twitter and Instagram. The generated survey questionnaire was in English; therefore, only bilingual individuals were included in the study.

\section{Participants \& Procedure}

The participants' demographic information was also obtained likewise (age, gender, education, occupation, monthly income \& ethnicity). The mean age of participants was 25.40 years with SD 5.73 and a mean monthly income of PKR 72,226 (US\$ 450). In this connection, most of the participants were female $(84,76 \%)$ and $26(23 \%)$ were male. Among the participants 56 (50.9) were skilled workers, $51(46.4)$ were students and $3(2.7 \%)$ were unskilled. Likewise, in reference to educational attainment, most of participants $(81,73.6 \%)$ were postgraduates and $29(26.4 \%)$ had a bachelor's degree. In this connection, sixty-three of the participants (57\%) reported that they did not believe in conspiracy theories related to COVID-19 while 47 (42\%) said that they did. In reference to the ethnicity, most of the participants $(82,74.5 \%)$ identified themselves as Punjabi.

\section{Measures}

A total of 22 items were used to construct the survey questionnaire of COVID-19 Conspiracies Belief Questionnaire. The initial item pool (in English) was done through a deductive approach by consulting the relevant literature (Burisch, 1984). The researcher generated items, and the content validity of each item was assessed on a 10-point scale by three other psychologists who held a PhD degree in Psychology (Field, 2013). After this, pilot testing was carried out with a sample of 20 individuals with a mean age of 21 years to determine the item clarity. I asked the participants whether they disagreed or agreed with 21 prevailing conspiracy theories related to COVID-19 on a five-point Likert scale where $1=$ strongly disagree and $5=$ strongly agree. The following are examples of some of the questions asked: I believe $5 \mathrm{G}$ is responsible for Covid-19; I believe COVID-19 accidentally escaped from the Chinese lab where bat viruses were under research; I believe COVID-19 was planted by American Army in China to destroy China economy; I believe that e-marketing companies spread COVID-19; I believe, COVID-19 is one step toward constitution of the greater Israel. One additional item was asked, combined with the Muslim conspiracy theories, about Muslims' belief that COVID-19 is punishment from Allah for human sins.

Later on, pilot study data was also included in the final data analysis. After collecting the data from 110 participants, Cronbach's alpha reliability for the questionnaire was calculated, and it was strong. i.e. 0.95. The inter-item correlation ranged between (0.5-.86). This confirmed that items had enough variance in common to justify treating them as a scale for this population. Subsequently, KMO and Bartlett's test was administered to check the sample adequacy for factor analysis. $\mathrm{KMO}=.895$ and Bartlett's Test of Sphericity, Chi-square $=2205.658, \mathrm{p}<$. ooo, df $=253$ shows the adequacy of the sample for the further analysis (Kaiser, 1960). The data was explored through exploratory factor analysis using varimax rotation with eigenvalue above 0.1 considered a rule for factor construction (Kaiser, 1960). Principle component analysis and varimax rotation with absolute suppression below 0.3 were used (Norman \& Streiner, 1994). All 
items were retained, and varimax rotation came up with a four-factor solution, and item factor loading ranged between $(.31$ - .82) (See Table 1$)$. After examination of the items, factors were relabeled.

Table 1

Factor Loading for Items

\begin{tabular}{|c|c|c|c|c|c|}
\hline Relabeling & Items & I & II & III & IV \\
\hline \multirow{13}{*}{$\begin{array}{l}\text { Political \& economic } \\
\text { conspiracy }\end{array}$} & Bioweapon developed by Israel & .824 & & & \\
\hline & Bioweapon developed by America & .822 & & & \\
\hline & Israel control mobility globally via ID microchips & .794 & & & \\
\hline & By America to create hatred towards the Chinese & .785 & & & \\
\hline & By American Army to destroy China's economy & .773 & & & \\
\hline & One step towards constitution of a greater Israel & .773 & & & \\
\hline & By WHO to gain control by developing psychological fear & .730 & & & \\
\hline & Control people's emotions globally via ID microchips & .705 & & & \\
\hline & Bill Gates is responsible & .694 & & & \\
\hline & Spread to give a boost to the use of debit/credit card & .663 & & & \\
\hline & Reduce the elderly to cut down the burden on public funds & .636 & & & \\
\hline & Spread by digital companies to increase online businesses & .629 & & & \\
\hline & To control the global birth rate & .540 & & & \\
\hline \multirow{5}{*}{$\begin{array}{l}\text { Global modernization } \\
\text { conspiracy }\end{array}$} & Spread because of LGBTs & & .714 & & \\
\hline & Spread through genetically modified crops & & .695 & & \\
\hline & Spread by e-marketing companies & & .694 & & \\
\hline & $5 \mathrm{G}$ is responsible & & .683 & & \\
\hline & By developing countries to get relief from debt from IMF & & .669 & & \\
\hline \multirow[t]{3}{*}{ China conspiracy } & Bioweapon developed by China & & & .828 & \\
\hline & China to sell their medical equipment to the world & & & .812 & \\
\hline & Chinese lab where bat viruses were being researched & & & .657 & \\
\hline Faith & It is a form of punishment by God & & & & .741 \\
\hline
\end{tabular}

\section{Data Analysis}

Preliminary analysis was conducted in order to understand descriptive analysis for demographics and belief in conspiracy theories. In addition to find out the gender difference, a chi-square test of independence was carried out. Binary logistics were used to determine association between demographic characteristics and a generalized tendency to believe in conspiracy theories. The dependent variable of study, belief in conspiracy theories, had a categorical response coded 1 for yes and o for no; so, the odds ratio (OR) with a 95\% confidence interval (CI) and P-value are reported.

\section{RESULTS OF STUDY}

In this section, the porocedures and methods for conducting research have been presented. This study used the correlational research design that suggested for the development of scientific knowledge for current study by using different tools and teachiniques to reach the conclusion systematically. 


\section{Table 2}

Frequencies \& Percentages for Conspiracy beliefs in Pakistani Muslims during COVID-19

\begin{tabular}{|c|c|c|c|c|c|}
\hline \multirow{2}{*}{$\begin{array}{l}\text { Variables } \\
\text { Political and economic conspiracy }\end{array}$} & \multicolumn{5}{|c|}{ Frequency f (\%) } \\
\hline & SD & D & SA & A & SAG \\
\hline Bill Gates is responsible & $49(44.5)$ & $31(28.2)$ & $19(17.3)$ & $6(5.5)$ & $5(4.5)$ \\
\hline By American Army to destroy China's economy & $18(16.4)$ & $26(23.6)$ & $40(36.4)$ & $22(20)$ & $4(3.6)$ \\
\hline By America to create hatred towards the Chinese & $25(22.7)$ & $24(21.8)$ & $40(36.4)$ & $17(15.5)$ & $4(3.6)$ \\
\hline Bioweapon developed by America & $20(18.2)$ & $26(23.6)$ & $29(26.4)$ & $28(25.5)$ & $7(6.4)$ \\
\hline Bioweapon developed by Israel & $20(18.2)$ & $32(29.1)$ & $30(27.3)$ & $20(18.2)$ & $8(7.3)$ \\
\hline Israel control mobility globally via ID microchips & $30(27.3)$ & $29(26.4)$ & $29(26.4)$ & $16(14.5)$ & $6(5.5)$ \\
\hline Control people's emotions globally via ID microchips & $28(25.5)$ & $26(23.6)$ & $35(31.8)$ & $15(13.6)$ & $6(5.5)$ \\
\hline To control the global birth rate & $26(23.6)$ & $30(27.3)$ & $35(31.8)$ & $15(13.6)$ & $4(3.6)$ \\
\hline Spread by digital companies to increase online businesses & $34(30.9)$ & $44(40.0)$ & $21(19.1)$ & $7(6.4)$ & $4(3.6)$ \\
\hline Spread to give a boost to the use of debit/credit card & $34(30.9)$ & $36(32.7)$ & $25(22.7)$ & $9(8.2)$ & $6(5.5)$ \\
\hline Reduce the elderly to cut down the burden on public funds & $27(24.5)$ & $36(32.7)$ & $28(25.5)$ & $14(12.7)$ & $5(4.5)$ \\
\hline By WHO to gain control by developing psychological fear & $36(32.7)$ & $32(29.1)$ & $26(23.6)$ & $12(10.9)$ & $4(3.6)$ \\
\hline $\begin{array}{l}\text { One step towards the constitution of a greater Israel } \\
\text { Global modernization conspiracy }\end{array}$ & $28(25.5)$ & $34(30.9)$ & $30(27.3)$ & $12(10.9)$ & $6(5.5)$ \\
\hline $5 \mathrm{G}$ is responsible & $46(41.8)$ & $35(31.8)$ & $19(17.3)$ & $8(7.3)$ & $2(1.8)$ \\
\hline Spread by & $37(33.6)$ & $43(39.1)$ & $18(16.4)$ & $9(8.2)$ & $3(2.7)$ \\
\hline By developing countries to get relief from debt from IMF & $37(33.6)$ & $27(24.5)$ & $31(28.2)$ & $10(9.1)$ & $5(4.5)$ \\
\hline Spread through genetically modified crops & $26(23.6)$ & $50(45.5)$ & $27(24.5)$ & $5(4.5)$ & $2(1.8)$ \\
\hline Spread because of LGBTs & $50(45.5)$ & $41(37.3)$ & $15(13.6)$ & $3(2.7)$ & $1(0.9)$ \\
\hline China conspiracy & & & & & \\
\hline Chinese lab where bat viruses were being researched & $19(17.3)$ & $26(23.6)$ & $39(35.5)$ & $24(21.8)$ & $2(1.8)$ \\
\hline China to sell their medical equipment to the world & $28(25.5)$ & $39(35.5)$ & $30(27.3)$ & $10(9.1)$ & $3(2.7)$ \\
\hline $\begin{array}{l}\text { Bioweapon developed by China } \\
\text { Faith }\end{array}$ & $22(20)$ & $32(29.1)$ & $31(28.2)$ & $19(17.3)$ & $6(5.5)$ \\
\hline It is a form of punishment by God & $14(12.7)$ & $09(8.2)$ & $28(25.5)$ & $38(34.5)$ & $21(19.1)$ \\
\hline
\end{tabular}

Strongly Disagree: SD, Disagree: D, Somewhat Agree: SA, Agree: A, Strongly Agree: SAG

Table 1 shows that around 59\%, 60\%, 55\%, 51\%, 58\%, 52\% and 51\% of the participants gave responses between 'somewhat agree' and 'strongly agree' for following beliefs about COVID-19: accidentally escaped from the Chinese lab where bat viruses were being researched; planted by American Army in China to destroy China's economy; planted by America in China to create hatred towards Chinese; a bioweapon developed by China; a bioweapon developed by America; the bioweapon developed by Israel; and the vaccination for COVID-19 will be used to control people's emotions globally by injecting ID microchips, respectively. In this connection, most of the participants (79\%) believed that the COVID-19 is the punishment from Allah for human sins.

Table 2 shows the gender difference for the following conspiracy beliefs: COVID-19 is spread through genetically modified crops; COVID-19 is spread because of the LGBTs (lesbian, gay, bisexual, and transgender); Bill Gates is responsible; the vaccination for COVID-19 will control people's mobility globally through injected ID microchips made by Israel; the vaccination for COVID-19 will be used to control people's emotions globally through injected ID microchips; and the WHO manages COVID-19 spread for Bill Gates in order to gain control over the world by developing psychological fear. Consequently, the results showed that male participants were more likely to disagree with the above-mentioned/stated conspiracy beliefs than the female participants. 
Table 3

Result of Chi-square test on Gender Differences for Belief in Conspiracy

\begin{tabular}{|c|c|c|c|c|}
\hline Variables & Males & Females & Chi-square & p-values \\
\hline \multicolumn{5}{|l|}{ Global modernization conspiracy } \\
\hline \multicolumn{5}{|c|}{ Spread through genetically modified crops } \\
\hline Strongly Disagree & $26.5 \%$ & $15.4 \%$ & \multirow{5}{*}{9.18} & \multirow{5}{*}{.03} \\
\hline Disagree & $49.4 \%$ & $34.6 \%$ & & \\
\hline Somewhat Agree & $21.7 \%$ & $34.6 \%$ & & \\
\hline Agree & $2.4 \%$ & $11.5 \%$ & & \\
\hline Strongly Agree & $0.9 \%$ & $3.8 \%$ & & \\
\hline \multicolumn{5}{|l|}{ Spread because of LGBTs } \\
\hline Strongly Disagree & $50.6 \%$ & $30.8 \%$ & \multirow{5}{*}{8.8} & \multirow{5}{*}{.04} \\
\hline Disagree & $37.3 \%$ & $34.6 \%$ & & \\
\hline Somewhat Agree & $9.6 \%$ & $26.9 \%$ & & \\
\hline Agree & $2.8 \%$ & $3.8 \%$ & & \\
\hline Strongly Agree & $0.9 \%$ & $3.8 \%$ & & \\
\hline \multicolumn{5}{|l|}{ Political and economic conspiracy } \\
\hline \multicolumn{5}{|l|}{ Bill Gates is responsible } \\
\hline Strongly Disagree & $51.8 \%$ & $23.1 \%$ & \multirow{5}{*}{22.51} & \multirow{5}{*}{.000} \\
\hline Disagree & $32.5 \%$ & $15.4 \%$ & & \\
\hline Somewhat Agree & $8.4 \%$ & $46.5 \%$ & & \\
\hline Agree & $4.8 \%$ & $3.8 \%$ & & \\
\hline Strongly Agree & $2.4 \%$ & $11.5 \%$ & & \\
\hline \multicolumn{5}{|c|}{ Israel controls mobility globally via ID microchips } \\
\hline Strongly Disagree & $31.3 \%$ & $15.4 \%$ & & \\
\hline Disagree & $31.3 \%$ & $11.5 \%$ & \multirow{4}{*}{10.83} & \multirow{4}{*}{.021} \\
\hline Somewhat Agree & $20.5 \%$ & $46.2 \%$ & & \\
\hline Agree & $13.3 \%$ & $19.2 \%$ & & \\
\hline Strongly Agree & $3.6 \%$ & $7.7 \%$ & & \\
\hline \multicolumn{5}{|c|}{ Control people's emotions globally via ID microchips } \\
\hline Strongly Disagree & $28.9 \%$ & $15.4 \%$ & \multirow{5}{*}{10.36} & \multirow{5}{*}{.03} \\
\hline Disagree & $28.9 \%$ & $7.7 \%$ & & \\
\hline Somewhat Agree & $26.5 \%$ & $50 \%$ & & \\
\hline Agree & $12 \%$ & $19.2 \%$ & & \\
\hline Strongly Agree & $3.6 \%$ & $7.7 \%$ & & \\
\hline \multicolumn{5}{|c|}{ WHO to gain control by developing psychological fear } \\
\hline Strongly Disagree & $38.5 \%$ & $15.4 \%$ & \multirow{4}{*}{11.55} & \multirow{4}{*}{.01} \\
\hline Disagree & $32.5 \%$ & $19.2 \%$ & & \\
\hline Somewhat Agree & $18.1 \%$ & $42.3 \%$ & & \\
\hline Agree & $8.4 \%$ & $19.2 \%$ & & \\
\hline Strongly Agree & $2.4 \%$ & $3.8 \%$ & & \\
\hline
\end{tabular}

Table 4

Binary Logistic Regression for Demographic Characteristics of Participants

\begin{tabular}{llccc}
\hline \multicolumn{1}{c}{ Variable } & \multicolumn{1}{c}{ Category } & OR & 95\% CI & p-value \\
\hline Age (years) & Young Adult & 1.000 & - & - \\
\multirow{3}{*}{ Gender } & Adults & 1.52 & $.57-4.07$ & 0.403 \\
& Male & 1.000 & - & - \\
& Female & $3.16^{*}$ & $1.15-8.72$ & .02
\end{tabular}


Ashraf ... An Investigation On

\begin{tabular}{llccc} 
Education & Below Graduation & 1.000 & - & - \\
& Above Graduation & 1.09 & $.44-2.73$ & 0.84 \\
Occupation & Skilled & 1.000 & - & - \\
& Unskilled & .99 & $0.59-1.64$ & 0.96 \\
Monthly Income & Less than one Lac & 1.000 & - & - \\
\multirow{2}{*}{ Ethnicity } & More than one Lac & 0.91 & $0.33-2.48$ & 0.87 \\
& Punjabi & 1.000 & - & - \\
\hline
\end{tabular}

Note: ${ }^{*} \mathrm{p}<0.05$,

The binary logistic regression in Table 3 examined the relationship between the demographic characteristics of research participants and belief in conspiracy theories. The results revealed that the female participants were more likely to believe in conspiracy theories than the male participants.

\section{Table 5}

Binary Logistic Regression for Generalised Ideological Dimension

\begin{tabular}{|c|c|c|c|c|c|}
\hline No. & Variable & Category & OR & $95 \% \mathrm{CI}$ & P-value \\
\hline & Political and economic conspiracy & & & & \\
\hline 1 & Bill Gates is responsible & No & 1.000 & - & - \\
\hline & & Yes & 3.237 & $.38-27.80$ & .28 \\
\hline 2 & By American Army to destroy China's economy & No & 1.000 & - & - \\
\hline & & Yes & 1.455 & $.23-9.43$ & .69 \\
\hline 3 & By America to create hatred towards the Chinese & No & 1.000 & - & - \\
\hline & & Yes & 499 & .08-3.13 & 46 \\
\hline 4 & Bioweapon developed by America & No & 1.000 & - & - \\
\hline & & Yes & .483 & $.062-3.785$ & .49 \\
\hline 5 & Bioweapon developed by Israel & No & 1.000 & - & - \\
\hline & & Yes & 3.871 & $.573-26.157$ & .17 \\
\hline 6 & Israel control mobility globally via ID microchips & No & 1.000 & - & - \\
\hline & & Yes & $.067^{*}$ & $.005-.838$ & .04 \\
\hline 7 & Control people's emotions globally via ID microchips & No & 1.000 & - & - \\
\hline & & Yes & 1.473 & $.123-17.606$ & .76 \\
\hline 8 & To control the global birth rate & No & 1.000 & - & - \\
\hline & & Yes & $20.576^{*}$ & $1.639-258.33$ & .02 \\
\hline 9 & Spread by digital companies to increase online businesses & No & 1.000 & - & - \\
\hline & & Yes & .199 & $.004-10.740$ & .43 \\
\hline 10 & Spread to give a boost to the use of debit/credit card & No & 1.000 & - & - \\
\hline & & Yes & 6.995 & $.707-69.209$ & .09 \\
\hline 11 & Reduce the elderly to cut down the burden on public funds & No & 1.000 & - & - \\
\hline & & Yes & .504 & $.071-3.561$ & .49 \\
\hline 12 & By WHO to gain control by developing psychological fear & No & 1.000 & - & - \\
\hline & & Yes & $.080^{*}$ & $.008-.820$ & .03 \\
\hline 13 & One step towards the constitution of a greater Israel & No & 1.000 & - & - \\
\hline & & Yes & 1.140 & $.196-6.625$ & .88 \\
\hline & Global modernization conspiracy & & & & \\
\hline 14 & $5 \mathrm{G}$ is responsible & No & 1.000 & - & - \\
\hline & & Yes & .723 & $.15-3.39$ & .68 \\
\hline 15 & Spread by e-marketing companies & No & 1.000 & - & - \\
\hline
\end{tabular}




\begin{tabular}{lcccc} 
& Yes & .201 & $.004-10.463$ & .43 \\
16 By developing countries to get relief from debt from IMF & No & 1.000 & - & - \\
& Yes & 1.686 & $.405-7.025$ & .47 \\
17 Spread through genetically modified crops & No & 1.000 & - & - \\
& Yes & $.026^{* * *}$ & $.002-.311$ & .004 \\
18 Spread because of LGBTs & No & 1.000 & - & - \\
& Yes & $82.073^{* * *}$ & $4.563-1476.08$ & .003 \\
Role of China & & & & \\
19 Chinese lab where bat viruses were being researched & No & 1.000 & - & - \\
20 China to sell their medical equipment to the world & Yes & 1.744 & $.44-6.87$ & .43 \\
21 Bioweapon developed by China & No & 1.000 & - & - \\
& Yes & .499 & $.08-3.13$ & .46 \\
Faith & No & 1.000 & - & - \\
It is a form of punishment from God & Yes & .680 & $.105-4.398$ & .69 \\
\hline & & & & - \\
\hline
\end{tabular}

Note: ${ }^{*} \mathrm{p}<0.05,{ }^{* *} \mathrm{p}<0.01,{ }^{* * *} \mathrm{p}<0.001$.

The binary logistic regression in Table 4 shows that participants largely believed in following conspiracy theories related to COVID-19: vaccination of COVID-19 will control people mobility globally through injected ID microchips made by Israel; vaccination for COVID-19 will contain elements that control global birth rate; WHO manages COVID-19 spread for Bill Gates so as to gain control over world by developing psychological fear; COVID-19 is spread over genetically modified crops and COVID-19 is spread because of LGBTs (lesbian, gay, bisexual \& transgender people).

\section{DISCUSSION}

Conspiracy beliefs are an unconfirmed and doubtful explanation of the role of malicious forces in plotting any major event (Prooijen \& Van Vuget, 2018). Literature indicates that people hold conspiracy beliefs at times of societal crises (Prooijen \& Douglas, 2017). During a pandemic, people usually try to get answers through conspiracy beliefs about why it has happened, who is involved in it and who can benefit from all this (Wood, 2018). However, such beliefs can affect negatively the adherence to preventive health measures during pandemics (Swami et al 2014). Therefore, in this study attempt has been made to find out whether Pakistani Muslims believe in conspiracies related to COVID-19 or not. Surprisingly, $47 \%$ of research participants believed in conspiracy theories related to COVID1-19, though findings are consistent with research on the prevalence of conspiracy theories among polish adults (Duplaga, 2020). And in contracts to Pew research on American adults in which $23 \%$ of research participants believe in conspiracy theories.

The data confirmed that Pakistani Muslims believe in some conspiracy theories about COVID19. From the list of conspiracies asked about in the survey, most of the respondents responded that they strongly agreed or somewhat agreed with them. Like other studies, almost $59 \%$ of the participants believed that COVID-19 was escaped from Chinese elaborates (Allington et al, 2020). In contrast to Allington and Dhavan (2020), only 10\% of the participants of this study reported that COVID-19 seemed to be related to $5 \mathrm{G}$. It can also be seen that most of participants believed that powerful groups planted COVID-19 to advance the malicious agenda, for example, to gain 
control over the world through vaccination, or to rule the world through the strong economy. Most of the respondents agreed that America planted this to destroy the China's economy. Like other published research, data revealed that women believed more in conspiracy theories than men (Sallam et al, 2020). Thus, in line with the findings of Uscinski et al (2020), there was no significant association was found between education and belief in the conspiracy theories. In contrast to Duplaga (2020), no significant association was found between age, education, and occupation.

Despite believing in different conspiracy theories, most research participants agreed that COVID19 is a punishment from God for human sins. This can be considered the novel finding about Muslims who believe that they are accountable for their sins in this world and life after death. And they believe in Quranic verses which Said "He [Allah] has the power to send punishment on you from above or from under your feet (Quran, 6:65). Muslims also believe Allah sent that plague in the past to unspecified groups. So this finding can explain that more than conspiracy theories Muslims of Pakistan had belief in that this disease is Divine and a result of mankind sins. Based on the results, it can be concluded that people may respond less to cooperate with public health safety measures such as the strict quarantine and social distancing due to holding conspiracy beliefs. Previous literature suggested that government faces fatal effects on public health during HIV epidemic in South Africa (Simelela et al. 2015). Therefore, this research will help health policymakers to counter conspiracy beliefs hold by Pakistani Muslims. Moreover, COVID-19 Conspiracies Belief Questionnaire is expected to contribute to future research and clinical events to investigate and ultimately improve safety health measures against spread of COVID-19.

\section{CONCLUSION}

This is the first study to research Pakistani Muslims' beliefs in the conspiracy theories related to COVID-19. The author believes that conspiracy theories about COVID-19 can put public health at risk by discouraging people from following the preventive measures advocated by the WHO. In this connection, this dangerous lack of adherence to the standard operational procedures (SOPs) related to precautions against COVID-19 ultimately affects the political, social, and the financial strategies that the countries are employing. Therefore, the findings of this research can enable local and national governing bodies to develop knowledge-based strategies to tackle conspiracy beliefs. Otherwise, public health efforts will fail to control the viral spread and the world may ready to witness another fatal global pandemic (Morens et al., 2020). Therefore, it can also be concluded that due to belief in conspiracy theories, people may be less likely to vaccinate themselves as results of the study indicated the research participants' belief that the vaccination of COVID-19 is an attempt to control people's mobility globally through injected ID microchips.

Consequently, it can be supported through Jolley and Douglas (2014) argument that those who mistrust government policies were likely to have anti-vaccination conspiracy beliefs. This study has several limitations, and future research may address the following limitations. First data was gathered between May and June 2020, two months after the pandemic was announced; therefore, studies conducted after this time reflect different findings and contain some other conspiracies. Second, this research explains association so it cannot infer any causality; thus, experimental or longitudinal research may introduce different results. Third, the sample was collected online based on convenience sampling; consequently, the absence of the probability 
sampling of the target population may indicate caution to generalize results. Furthermore, it is suggested that the future research should use more operationalized constructs and study the association between anxiety, adherence to the public health safety measures, and conspiracy theories.

\section{REFERENCE}

Abalakina, M., Stephan, W. G., Craig, T., \& Gregory, L. (1999). Beliefs in conspiracies. Political Psychology, 20, 637-647.

Allington, D., \& Dhavan, N. (2020). The relationship between conspiracy beliefs and compliance with public health guidance with regard to COVID-19. Preso da: https:// kclpure. kcl. ac. uk/portal/files/127048253/Allington_and_Dhavan_2020.pdf.

Allington, D., Duffy, B., Wessely, S., Dhavan, N., \& Rubin, J. (2020). Health-protective behaviour, social media usage and conspiracy belief during the COVID-19 public health emergency. Psychological medicine, 1-7.

Avaaz. (2020). How Facebook can flatten the curve of coronavirus infodemic: study indicates Facebook is rife with bogus cures and conspiracy theories that remain on the platform long enough to put millions of people at risk. Report published by Avaaz, London. Retrieved from https://avaaz images.avaaz.org/facebook_coronavirus_misinformation. pdf.

Burisch, M. (1984). Approaches to personality inventory construction: A comparison of merits. American Psychologist, 39(3), 214-227.

Douglass, W. C. (1989). AIDS: The end of civilization. Clayton, GA: Valet Freeman, D., \& Bentall, R. P. (2017). The concomitants of conspiracy concerns. Social Psychiatry and Psychiatric Epidemiology, 52(5), 595-604.

Duplaga, M. (2020). The determinants of conspiracy beliefs related to the COVID-19 pandemic in a nationally representative sample of internet users. The International journal of environmental research and public health, 17(21), 7818. doi:10.3390/ijerph17217818.

Goertzel, T. D. (1994). The Belief in the conspiracy theories. The Political Psychology, 15, 731742. Bates, K. D. (1990) Is it genocide? Essence, September, 76-117.

Graham, B. S., \& Sullivan, N.J. (2018). Emerging viral diseases from a vaccinology perspective: Preparing for the next pandemic. Nature Immunology, 19, 20-28

Grzesiak, F. M. (2013). The effect of high-anxiety situations on conspiracy thinking. Current Psychology, 32, 100-118

Guess, A., Nagler, J., \& Tucker, J. (2019). Less than you think: prevalence and predictors of fake news dissemination on Facebook. Science Advances. 5, aau4586.

Hogg, R., Nkala, B., Dietrich, J., Collins, A., Closson, K., Cui, Z., Kaida, A. (2017). Conspiracy beliefs and knowledge about HIV origins among adolescents in Soweto. South Africa. PLOS ONE, 12(2), e0165087. https://doi.org/10.1371/ journal.pone.0165087.

Jolley, D., \& Douglas, K. (2014). The effects of anti-vaccine conspiracy theories on vaccination intentions. PLoS ONE, 9, e89177, doi.org/10.1371/journal.pone.0089177.

Jost, J. T., Ledgerwood, A., \& Hardin, C. D. (2008). Shared reality, system justification, and the relational basis of ideological beliefs. Social \& Personality Psychology Compass, 2, 171185 .

Kaiser, H. F. (1960). The application of electronic computers to factor analysis. Educational and Psychological Measurement, 20, 141-15. 
Li HO-Y., Bailey, A., Huynh, D., \& Chan, J. (2020). YouTube as a source of information on COVID19: a pandemic of misinformation? BMJ Global Health, 5, e002604.

Martínez, Y., \& Jiménez, L. F. (2017). Yellow fever outbreaks and Twitter: The Rumours and misinformation. American Journal of Infection Control, 45, 815-816.

Miller, J. M. (2020). Do COVID-19 conspiracy theory beliefs form a monological belief system? Canadian Journal of Political Science, 53, 319-326, doi:10.1017/ So008423920000517.

Morens, D. M., Daszak, P., \& Taubenberger, J. K. (2020). Escaping Pandora's Box-Another Novel Coronavirus. The New England Journal of Medicine. 382, 1293-1295.

Norman, G., \& Streiner, D. (1994). Biostatistics: The Bare Essentials. St Louis: Mosby Ofcom. (2020). Half of UK adults exposed to false claims about coronavirus. See https://www. ofcom.org.uk/about-ofcom/latest/features-andnews/half-of-uk-adults-exposed-to-false -claims about-coronavirus (accessed 18 May 2020).

Oi-Yee Li, H., Bailey, A., Huynh, D., \& Chan, J. (2020). Youtube as a source of information on COVID-19: A pandemic of misinformation? BMJ Global Health, 5, eo02604. doi:10. 1136/ bmjgh-2020-002604.

Pandey, A., Patni, N., Sing, M., Sood, A., \& Singh, G. (2010). Youtube as a source of information on the H1N1 influenza pandemic. American Journal of Preventative Medicine, 38(3), e1-e3.

Miller, J. M. (2020). Do COVID-19 conspiracy theory beliefs form a monological belief system? Canadian Journal of Political Science, 53, 319-326, doi:10.1017/ Soo08423920000517.

Morens, D. M., Daszak, P., \& Taubenberger, J. K. (2020). Escaping Pandora's Box-Another Novel Coronavirus. The New England Journal of Medicine. 382, 1293-1295.

Pennycook, G., Cannon, T., \& Rand, D. G. (2018) Prior exposure increases perceived accuracy of fake news. Journal of Experimental Psychology, 147, 1865-1880, doi:10. 1037/ xgeooo046.

Plohl, N., \& Musil, B. (2021). Modeling compliance with COVID-19 prevention guidelines: the critical role of trust in science. Psychology Health \& Medicine. 26(1),1-12. doi: 10.1080/ 13548506.2020.1772988.

Prooijen, J. W., \& Douglas, K. M. (2017). Conspiracy theories as part of history: The role of societal crisis situations. Memory Studies, 10 (3), 323-333, doi:10.1177\%2F175069801 7701615 .

Quran, 6:65: Oxford World's Classics Report, 12, 30-31.

Sallam, M., Dababseh, D., Yaseen, A., Al-Haidar, A., Ababneh, N. A., Bakri, F. G., \& Mahafzah, A. (2020). Conspiracy Beliefs Are Associated with Lower Knowledge and Higher Anxiety Levels Regarding COVID-19 among Students at the University of Jordan. International journal of environmental research and public health, 17(14), 4915. https://doi.org/ 10.3390/ijerph17144915.

Simelela N., Venter W.D., Pillay Y., \& Barron P. (2015). A Political and Social History of HIV in South Africa. Current HIV/AIDS Reports, 12:256-261. doi: 10.1007/s11904-015-02597.

Swami, V., Voracek, M., Stieger, S., Tran, U. S., \& Furnham, A. (2014). Analytic thinking reduces belief in conspiracy theories. Cognition, 133, 572-585.

Uscinski, J. E., \& Parent, J. M. (2014). American conspiracy theories. New York, NY: Oxford University Press

Uscinski, J. E., Enders, A. M., Seelig, M., Funchion, J., Everett, C., \& Murthi, M. (2020). Why do people believe COVID-19 conspiracy theories?. Harvard Kennedy School Misinformation Review, 1, 1-12 doi: https://doi.org/10.37016/mr-2020-015 
Van Prooijen, J. W., \& Jostmann, N. B. (2013). Belief in conspiracy theories: The influence of uncertainty and perceived morality. European Journal of Social Psychology, 43, 109115 .

Van Prooijen, J. W., \& Vugt, M. (2018). Conspiracy Theories: Evolved Functions and Psychological Mechanisms. Perspective on Psychological Science, 13, 770-788.

Wood, J. M (2018). Propagating and debunking conspiracy theories on Twitter during th 20152016 Zika virus outbreak. Cyber psychology, Behaviour \& Social Networking, 21 (8), 485-490, doi: 10.1089/cyber.2017.0669. 